\title{
Expression and clinicopathological significance of Mel-18 and Bmi-1 mRNA in gastric carcinoma
}

\author{
You-Wei Lu', ${ }^{1,2}$ Jin Li ${ }^{1,2}$, Wei-Jian Guo ${ }^{1,2^{*}}$
}

\begin{abstract}
Background: The Polycomb group $(P C G)$ genes are a class of regulators responsible for maintaining homeotic gene expression throughout cell division. PCG expression is deregulated in some types of human cancer. Both Bmi-1 and Mel-18 are of the key PCG proteins. We investigate the expression and clinicopathological roles of Mel-18 and Bmi-1 mRNA in gastric cancer.

Methods: The expression of Mel-18 and Bmi-1 in a series of 71 gastric cancer tissues and paired normal mucosal tissues distant from the tumorous lesion was assayed by quantitative real time RT-PCR. The correlation between Mel-18 and Bmi-1 mRNA expression, and between Mel-18 or Bmi-1 mRNA level and clinicopathological characteristics were analyzed.

Results: Expression of Mel-18 and Bmi-1 genes was variably detected, but overexpression of Bmi-1 mRNA and decreased expression of Mel-18 mRNA were the most frequent alteration. In addition, the expression of Bmi-1 and Mel-18 mRNA inversely correlates in gastric tumors. Moreover, a significant positive correlation between Bmi-1 overexpression and tumor size, depth of invasion, or lymph node metastasis, and a significant negative correlation between Mel-18 low-expression with lymph node metastasis or the clinical stage were observed.

Conclusion: Our data suggest that Mel-18 and Bmi-1 may play crucial but opposite roles in gastric cancer. Decreased Mel-18 and increased Bmi-1 mRNA expression was associated with the carcinogenesis and progression of gastric cancer. It is possible to list Bmi-1 and Mel-18 as biomarkers for predicting the prognosis of gastric cancer.
\end{abstract}

\section{Background}

The Polycomb group $(P c G)$ genes were first identified in Drosophila as a class of regulators responsible for maintaining homeotic gene expression throughout cell division [1], $P c G$ genes are conserved from Drosophila to mammals, and the expression levels of mammalian $P c G$ genes differ between different tissues and cell types [2], $P c G$ genes act as epigenetic silencers during embryo morphogenesis with a central role in the nervous system, heart, and skeleton development [3-7].In addition, PcG members have been involved in the regulation of such adult processes as the cell cycle, $\mathrm{X}$-inactivation, and hematopoiesis [8-14]. PcG expression is deregulated in some types of human cancer [15].Moreover, several PcG genes may regulate the self-renewal of specific stem

\footnotetext{
* Correspondence: guoweijian1@sohu.com

'Department of Medical Oncology, Fudan University Shanghai Cancer Center; China

Full list of author information is available at the end of the article
}

cell types, suggesting a link between the maintenance of cell homeostasis and carcinogenesis [16,17].

Bmi-1 is one of the key PcG proteins. It was initially identified as an oncogene that cooperated with c-Myc in the generation of mouse pre-B-cell lymphomas. It is also considered the first functional mammalian $P c G$ protooncogene to be recognized, and it has been implicated in axial patterning, hematopoiesis, cell cycle regulation, and senescence [18-21]. Human Bmi-1 gene is located at the short arm of chromosome 10p13 [22], The region is involved in chromosomal translocations in leukemia and is amplified in non-Hodgkin's lymphoma as well as in solid tumors [23]. Bmi-1 induces S-phase entry by inhibiting $\mathrm{Rb}$ function via repression of the INK4a/ARF locus [24-26]. Moreover, overexpression of Bmi-1 in mammary epithelial cells may activate telomerase and lead to immortalization [27]. Overexpression of Bmi-1 has been found in several human malignancies including breast cancer, colorectal cancer, nasopharyngeal carcinoma, melanoma, gastric cancer, and bladder
Ciomed Central

() 2010 Lu et al; licensee BioMed Central Ltd. This is an Open Access article distributed under the terms of the Creative Commons Attribution License (http://creativecommons.org/licenses/by/2.0), which permits unrestricted use, distribution, and reproduction in any medium, provided the original work is properly cited. 
cancer [28-33]. Overexpression of Bmi-1 often correlates with poorer prognosis and treatment failure [30,32-34]. Bmi-1 also plays an important role in self-renewal of hematopoietic stem cells, neural stem cells and mammary stem cells [35-37].

In addition to Bmi-1, mammalian cells also express a Bmi-1-related PcG protein Mel-18. The Mel-18 gene product is structurally highly similar to Bmi-1 protein. Interestingly, we have found that $B m i-1$ is negatively regulated by $\mathrm{Mel}-18$ and expression of $\mathrm{Mel}-18$ negatively correlates with $\mathrm{Bmi-1}$ in breast tumors, and $\mathrm{Mel}-18$ overexpression in breast cancer cell line MCF7 results in downregulation of Bmi-1 and reduction of transformed phenotype [38]. Negative correlation between Bmi-1 and Mel-18 expression was also recently reported in hematopoietic stem cells [39]. Lee et al. also recently reported that overexpression of $\mathrm{Mel}-18$ inhibits growth of breast cancer cells [40]. These data suggested that Mel-18 acts as a potential tumor suppressor. However, the function of Mel-18 is still debatable. In few other studies, it was found that similar to Bmi-1, Mel-18 can act as an oncogene [41,42]. So, the role of Mel-18 in cancers other than breast cancers and different pathological conditions is still not clear and need to be clarified.

Gastric cancer is one of the most common malignancies throughout the world. It has been reported that $B m i-1$ is overexpressed in gastric cancer and is an independent prognosis factor [32]. We have also studied the expression of Mel-18 and Bmi-1 in gastric tumors by immunohistochemistry (IHC). We found that gastric tumor tissues expressed significantly higher Bmi-1 and lower Mel-18, and the expression of Mel-18 negatively correlated with Bmi-1; there was a significant positive correlation between Bmi-1 expression with lymph node metastasis, or clinical stage, but there was no obvious correlation between Mel-18 expression and clinicopathological factors; downregulation of Bmi-1 by Mel-18 overexpression or knockdown of Bmi-1 expression was accompanied by decreased transformed phenotype and migration ability in gastric cancer cell lines in in vitro study [33]. So, the results of Bmi-1 expression correlated with lymph node metastasis or clinical stage in in vivo study was accordance with the results in in vitro study, while the results of no correlation was found between Mel-18 expression and clinicopathological factors in in vivo study was not accordance with the results in in vitro study, we suspected that one of the reason may due to the reliability of IHC method which was used to detect the expression of Bmi-1 and Mel-18 in tumor tissues in most paper of literature including our previous study. This method lacks standard procedure and evaluation criterion and its' reliability depends on the specific of antibody. The results of quantitative Real time RT-PCR (QRT-PCR) with specific primer is more reliable than that of IHC to measure the gene expression level especially for Mel-18, which lacks specific mouse monoclonal antibody till now. Here, we examine the expression of Mel-18 and Bmi-1 at mRNA level by using QRT-PCR method in a series of gastric cancer, and evaluate the correlation between $\mathrm{Mel}-18$ and Bmi-1 expression levels. Furthermore, a correlation study between expression levels of both the analyzed genes and several clinical pathologic variables of the tumors was designed. In this study, we characterized the expression profile of Mel-18 and Bmi-1, and their clinical significance in gastric cancer.

\section{Materials and methods \\ Clinical samples}

Human gastric cancer samples were obtained from patients who underwent surgery for gastric cancer in our hospital from 2007 to 2008. All of the patients didn't receive prior chemotherapy or radiotherapy before surgery. A total of 71 fresh gastric tissues and paired normal mucosal tissues distant from the tumorous lesion were removed and frozen in liquid nitrogen and stored at $-80^{\circ} \mathrm{C}$ until further use. After the diagnosis of gastric cancer was confirmed, RNA was extracted with Trizol reagent (Invitrogen) according to the manufacturer's protocol from the cancerous and paired normal tissues for further RT-PCR analysis of Mel-18 and Bmi-1 expression. By pathological types, all cases of gastric cancer are adenocarcinomas.

The clinicopathologic variables were obtained from the medical records and the disease stages of the patients were classified according to the 2002 UICC gastric cancer TNM staging system. Prior patients' consent and approval from the Institute Research Ethics Committee were obtained for the use of clinical materials described in the present study.

\section{Quantitative real time RT-PCR (QRT-PCR) assays}

The QRT-PCR was carried out as described using Brilliant SYBR Green QRT-PCR Master Mix, 2-Step kit (Stratagene, La Jolla, CA) [43]. cDNA was synthesized using reverse transcriptase, and the PCR amplification was carried out using PTC-200 Real Time PCR system (MJ Research Inc, USA). The primers for QRT-PCR were Glyceraldehyde-3-phosphate dehydrogenase $(G A P D H)$ forward (F)-5' GCTGAACGGGAAGCTCA CTG-3',GAPDH reverse (R)- 5'GTGCTCAGTGTAGCC CAGGA3'; Bmi-1 F 5' GCTTCAAGATGGCCGCTTG 3',Bmi-1 R 5'-TTCTCGTTGTTCGATGCATTTC-3'; and $\mathrm{Mel}-18$ F 5'- GATGGATGTGCCCAGCAAGT-3', Mel-18 R 5'GGAGCCTTGT CGCTGACTGA-3'. All reactions were done in a $20-\mu \mathrm{l}$ reaction volume in biplicate. PCR amplification consisted of $10 \mathrm{~min}$ of an initial denaturation step at $95^{\circ} \mathrm{C}$, followed by 40 cycles of PCR 
at $95^{\circ} \mathrm{C}$ for $30 \mathrm{sec}, 58^{\circ} \mathrm{C}$ for $30 \mathrm{sec}$ and $72^{\circ} \mathrm{C}$ for $30 \mathrm{sec}$. Standard curves were generated and the relative amount of target gene mRNA was normalized to GAPDH. Specificity was verified by melt curve analysis and agarose gel electrophoresis. Data normalization and analysis an endogenous control, GAPDH present on the PCR was used for normalization. Each replicate cycle threshold (CT) was normalized to the average CT of endogenous control on a sample basis. The comparative CT method was used to calculate the relative quantification of gene expression. The following formula was used to calculate the relative amount of the transcripts in the gastric cancer samples and the control group, both of which were normalized to the endogenous control. $\Delta \Delta \mathrm{CT}=\Delta \mathrm{CT}$ (gastric cancer)- $\Delta \mathrm{CT}$ (control) for RNA samples. $\Delta \mathrm{CT}$ is the $\log 2$ difference in CT between the target genes and endogenous controls by subtracting the average CT of controls from each replicate. The fold change for each gastric cancer sample relative to the control sample $=2^{-\Delta \Delta \mathrm{CT}}$. When the expression showed a 2 -fold increase or decrease compared with normal counterpart tissue, it was considered as an altered expression.

\section{Statistical analysis}

All statistical analyses were done by SPSS 15.0 software package. Two-tailed P value less than 0.05 was considered statistically significant. In the set of RT-PCR analysis of fresh tumors and paired normal tissues, the ratio of Bmi-1 and Mel-18 mRNA expression was not normally distributed. Hence, the distribution was established by using $\log _{10}$, and geometric averages. The correlation between Bmi-1 and Mel-18 expression levels was analyzed by the Pearson coefficient test. The correlation between Bmi-1 or Mel-18 expression and clinicopathologic characteristics was analyzed by ANOVA.

\section{Results}

\section{Expression of Bmi-1 and Mel-18 at mRNA level inversely correlates in gastric tumors}

Our previous data showed an inverse correlation between $\mathrm{Bmi}-1$ and $\mathrm{Mel}-18$ expression in breast cancer cells and breast cancer tissues. Based on these data, we hypothesized that gastric cancer may also express high Bmi-1 and low Mel-18. To probe this hypothesis, we studied the expression of $\mathrm{Mel}-18$ and Bmi-1 in gastric tumors by QRT-PCR. QRT-PCR analysis showed that 35 of 71 (49.3\%) fresh gastric tumor tissues overexpressed Bmi-1, and 46 of 71 (64.79\%) expressed low levels of Mel-18, compared with paired normal gastric mucosal tissues. (Table 1, Figure 1).

The correlation between Bmi-1 and Mel-18 expression at mRNA level was further analyzed by the Pearson coefficient correlation analysis, which showed a strong negative correlation $(\mathrm{r}=-0.252, \mathrm{P}=0.034)$.
The correlation between the expression of $\mathrm{Mel}-18$ or Bmi1 with clinicopathologic characteristics

We found a significant positive correlation between Bmi-1 overexpression and tumor size, depth of invasion ( $\mathrm{T}$ classification), or lymph node metastasis ( $\mathrm{N}$ classification). The expression of $B m i-1$ was higher in the patients with bigger tumor, deeper invasion, or positive lymph node metastasis. We also found that there was a significant negative correlation between $\mathrm{Mel}-18$ expression with lymph node metastasis or the clinical stage. Its expression was lower in the patients with lymph node metastasis, or late stage disease (Table 2).

\section{Discussion}

Mammalian PcG protein complexes are generally classified into two distinct types: Polycomb repressive complexes 1 and 2 (PRC1 and PRC2). Mel-18 protein product is a constituent of mammalian PRC1 together with M33, Bmi-1 or rae28/Mph-1, and Scmh1 [1,44-47]. In human tumors, some reports have showed alterations in PcG expression, in such human hematologic malignancies as nodal B-cell lymphomas $[48,49]$, mantle cell lymphomas [23,50], and Hodgkin's lymphomas $[13,51,52]$.It has been reported that solid tumors, such as lung cancers [53], medulloblastomas [3], liver [54], penis [55], breast [28,56], colon [57], and prostate carcinomas [58], also display disturbed $P c G$ gene expression.

Bmi-1 is one of the most important PcG proteins that is known to regulate proliferation and senescence in mammalian cells, and plays an important role in selfrenewal of stem cells. It can not only immortalize human mammary epithelial cells (HMECs) [27], but also can cooperate with $\mathrm{H}$-Ras to transform HMECs and transform keratinocytes [59,60]. Abnormal expression of Bmi-1 has been found in several human cancers and its overexpression is often correlated with poor prognosis in many types of malignances [28-34]. Overexpression of Bmi-1 in gastric cancer has been previously reported $[32,61]$. It was found that Bmi-1 overexpression was highly correlated with tumor size, clinical stage, lymph node metastasis and $\mathrm{T}$ classification [32]. In another study, Bmi-1 expression was closely related with the Lauren's and Borrmann's classification and clinical stage in gastric cancer [61]. We also found that gastric tumor tissues expressed significantly higher Bmi-1, and Bmi-1 overexpression correlated with lymph node metastasis, or clinical stage, which was accordance with the results in in vitro study that knockdown of Bmi-1 expression was accompanied by decreased transformed phenotype and migration ability in gastric cancer cell lines [33]. In these studies Bmi-1 was detected at protein level by IHC method. Here we detected $B m i-1$ at mRNA level by QRT-PCR method and found that $B m i-1$ is overexpressed in gastric tumors and Bmi-1 overexpression 
Table 1 Frequencies of altered expression of Bmi-1 and Mel-18 in the 71 gastric cancer tissues

\begin{tabular}{lcccccc}
\hline Gene & \multicolumn{2}{c}{ Decreased expression } & \multicolumn{2}{c}{ Normal expression } & \multicolumn{2}{c}{ Overexpression } \\
\cline { 2 - 7 } & Frequency & Percentage & Frequency & Percentage & Frequency & Percentage \\
\hline Bmi-1 & 9 & $12.68 \%$ & 27 & $38.03 \%$ & 35 & $49.30 \%$ \\
Mel-18 & 46 & $64.79 \%$ & 20 & $28.17 \%$ & 5 & $7.04 \%$ \\
\hline
\end{tabular}

correlates with tumor size, depth of invasion ( $\mathrm{T}$ classification), or lymph node metastasis ( $\mathrm{N}$ classification), which confirms previous observation of Bmi-1 at protein level. It suggests that Bmi-1 may play a crucial role and act as an oncogene in gastric cancer, and associated with the carcinogenesis, progression, and metastasis of gastric cancer.

Mel-18 was originally cloned from B16 mouse melanoma cells [62]. Mel-18 may bind to the nucleotide sequence 5'-GACTNGACT-3', which is present in the promoter region of certain genes. One of the unique target genes of $\mathrm{Mel}-18$ is c-Myc transcriptionally repressed by $\mathrm{Mel}-18$. In mature resting B cells, Mel-18 negatively regulates $\mathrm{B}$ cell receptor-induced proliferation through the down-regulation of the c-Myc/cdc25 cascade $[63,64]$. Our previous studies suggest that $\mathrm{Mel}-18$ is a physiologic regulator of $B m i-1$ expression and transcriptionally down-regulates $B m i-1$ expression during senescence in human fibroblasts and acts as a tumor suppressor in breast cancer $[38,43]$. Our previous data also showed an inverse correlation between Bmi-1 and Mel-18 expression at protein level in breast cancer and gastric cancer $[33,38]$. However, there was no correlation between Mel-18 expression at protein level and clinicopathological factors in in vivo study, which was not accordance with the results in in vitro study that Mel-18 overexpression was accompanied by decreased transformed phenotype and migration ability in gastric cancer cell lines[33]. One of the reasons may due to the reliability of IHC method depends on the specific of antibody. Mel-18 antibody is rabbit polyclonal and it's specific is not so good as Bmi-1 antibody which is mouse monoclonal. So we suspect the results of Mel-18 expression in tumor tissues at protein level detected by IHC may be not too reliable. To clarify this problem and further explore the role of Mel-18 in gastric cancer,
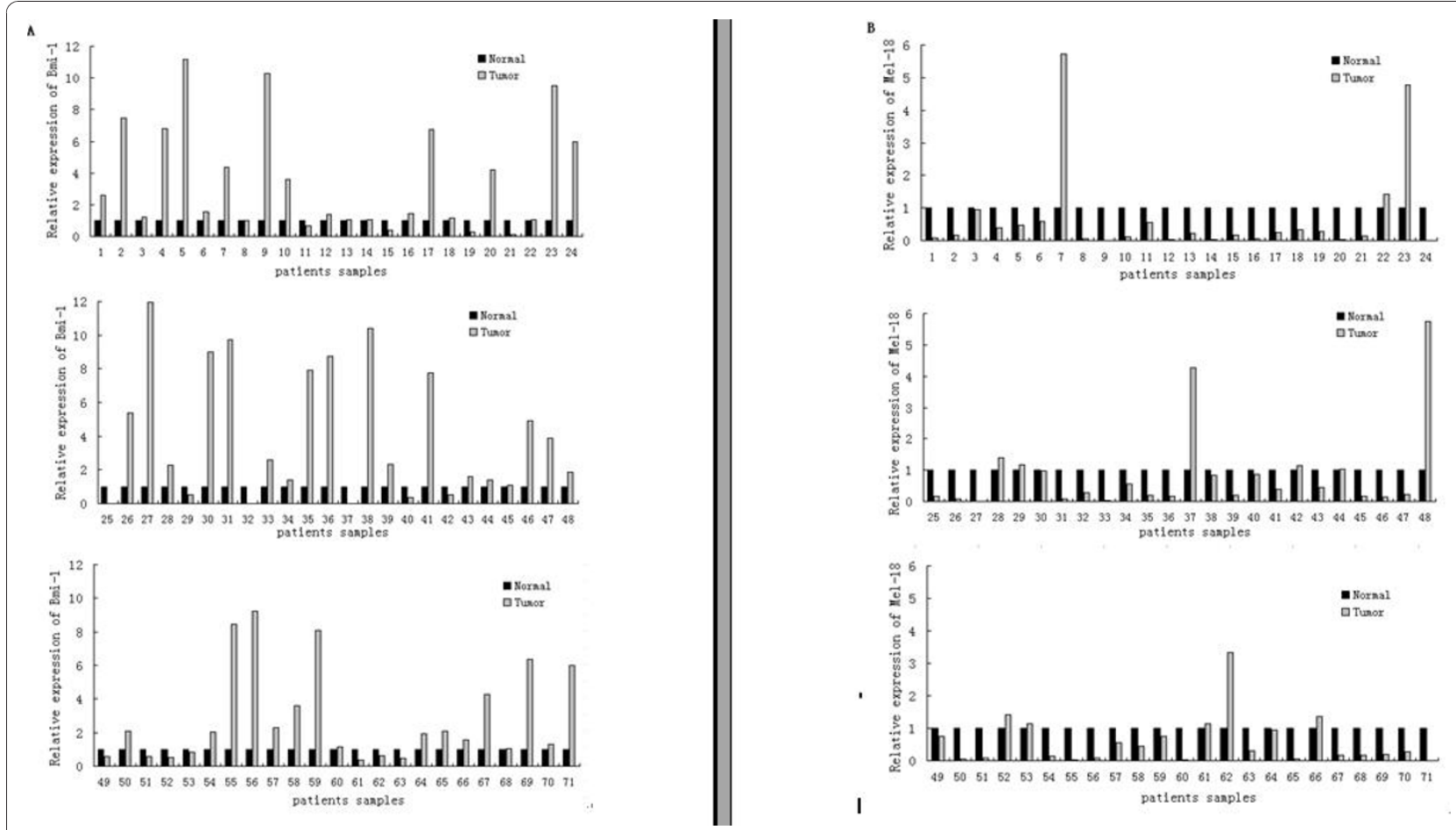

Figure 1 Comparative expression levels of Bmi-1 or Mel-18 were shown in 71 normal mucosal tissues and paired gastric cancer samples. A: Bmi-1 gene expression in human gastric cancer. B: Mel-18 gene expression in human gastric cancer. Expression level of target genes was displayed in a relative quantification method as a ratio between it in tumor tissues and that in normal tissues in the amounts of RNA. The expression level of Bmi-1 or Mel-18 in normal tissues was treated as 1 and the ratio of gene expression was the expression level of Bmi-1 or Mel18 in tumor tissues. 
Table 2 Correlations between the expression level of Bmi-1 or Mel-18 and clinical-pathologic variables

\begin{tabular}{|c|c|c|c|c|c|c|}
\hline \multirow[t]{2}{*}{ Variable } & \multicolumn{3}{|c|}{ Bmi-1 } & \multicolumn{3}{|c|}{ Mel-18 } \\
\hline & $\mathrm{n}$ & GA & $\mathbf{P}$ & $\mathrm{n}$ & GA & $\mathbf{P}$ \\
\hline \multicolumn{7}{|l|}{ Gender } \\
\hline Male & 58 & 1.568 & 0.687 & 58 & 0.259 & 0.309 \\
\hline Female & 13 & 1.958 & & 13 & 0.150 & \\
\hline \multicolumn{7}{|l|}{ Age(years) } \\
\hline$<60$ & 44 & 1.584 & 0.832 & 44 & 0.188 & 0.166 \\
\hline$\geq 60$ & 27 & 1.715 & & 27 & 0.336 & \\
\hline \multicolumn{7}{|l|}{ Size $(\mathrm{cm})$} \\
\hline$<4.5$ & 26 & 0.965 & $0.049^{*}$ & 26 & 0.206 & 0.335 \\
\hline$\geq 4.5$ & 45 & 2.213 & & 45 & 0.313 & \\
\hline \multicolumn{7}{|l|}{ Histology } \\
\hline Moderately differentiated & 13 & 0.989 & 0.248 & 13 & 0.185 & 0.584 \\
\hline Poorly differentiated & 58 & 1.827 & & 58 & 0.247 & \\
\hline \multicolumn{7}{|l|}{ T classification } \\
\hline $\mathrm{T} 1 / 2$ & 12 & 0.635 & $0.036^{*}$ & 12 & 0.399 & 0.242 \\
\hline $\mathrm{T} 3 / 4$ & 59 & 1.979 & & 59 & 0.210 & \\
\hline \multicolumn{7}{|l|}{ LNM } \\
\hline Negative & 16 & 0.762 & $0.044^{*}$ & 16 & 0.513 & $0.037^{*}$ \\
\hline Positive & 55 & 2.038 & & 55 & 0.186 & \\
\hline \multicolumn{7}{|l|}{ Distant metastasis } \\
\hline Negative & 68 & 1.663 & 0.597 & 68 & 0.232 & 0.645 \\
\hline Positive & 3 & 2.932 & & 3 & 0.372 & \\
\hline \multicolumn{7}{|l|}{ Clinical Stage } \\
\hline$|/| \mid$ & 22 & 0.949 & 0.075 & 22 & 0.506 & $0.010^{*}$ \\
\hline III/IV & 49 & 2.084 & & 49 & 0.166 & \\
\hline
\end{tabular}

Abbreviations: LNM, lymph node metastases; GA, geometrical average; *, Statistically significant. Statistically significant at 0.05 level (bilateral).

we detected it's expression at mRNA level by QRT-PCR in the present study. We found that most gastric tumor tissues (64.79\%) expressed decreased mRNA levels of Mel-18, and there was a strong negative correlation between Bmi-1 and Mel-18 expression at mRNA level. The results confirm the expression of Mel-18 and its' relationship with Bmi-1 at protein level in our previous study. More important, we also found that decreased expression of $\mathrm{Mel}-18$ correlated with lymph node metastasis or the clinical stage, which was accordance with the results in in vitro study that $\mathrm{Mel}-18$ overexpression was accompanied by decreased transformed phenotype and migration ability in gastric cancer cell lines in our previous study[33]. It provides more convincing in vivo data to suggest that $\mathrm{Mel}-18$ may play a crucial opposite role to Bmi-1 and act as a tumor suppressor in gastric cancer, and associated with the carcinogenesis, progression, and metastasis of gastric cancer.

In the current study we demonstrated that neoplastic cells in gastric cancer can't normally express Bmi-1 and Mel-18. We propose that abnormal PcG expression results in an altered composition of the PRC1 in gastric cancer cells, which probably affects expression of target genes involved in regulation of senescence and/or the cell cycle. Our observations add to the increasing evidence that $P c G$ genes are very important contributors to the carcinogenesis and progression of human tumors. We additonally found that both $\mathrm{Mel}-18$ and Bmi-1 correlated with lymph node metastasis. The mechanisms that they regulate cancer cells metastasis need to be further studied.

This research is the first time to study the correlation between $\mathrm{Mel}-18$ or $\mathrm{Bmi-1}$ expression at mRNA level and clinicopathological characteristics of gastric cancer by quantitative method. The expression of $B m i-1$ and Mel-18 was correlated with gastric cancer progress, advanced gastric cancer more likely expressed higher Bmi-1 and lower $\mathrm{Mel}$-18. Its clinical value deserves further study in a larger patient population.

\section{Conclusions}

In conclusion, our results suggest that $B m i-1$ and Mel-18 are coordinately deregulated. Interestingly, we observed a reverse correlation between the expression levels of $\mathrm{Bmi-1}$ and $\mathrm{Mel}-18$ in gastric cancer. Both Bmi-1 and Mel-18 are involved in the development and progression of gastric cancer. Bmi-1 and Mel-18 might be novel molecular markers for gastric cancer. But,the detailed mechanisms of regulation of Bmi-1 and $\mathrm{Mel}-18$ remained to be elucidated.

\section{Acknowledgements}

We thank for Chinese National Natural Scientific Funding (30873019, 81041074) and Scientific Research Foundation for the Returned Overseas Chinese Scholars from State Education Ministry for providing the fund, Wei Qin and LvZheng Cheng for helpful discussions and advice.

\section{Author details}

${ }^{1}$ Department of Medical Oncology, Fudan University Shanghai Cancer Center; China. ${ }^{2}$ Department of Oncology, Shanghai Medical College, Fudan University, Shanghai 200032, China.

\section{Authors' contributions}

LYW performed the experiment and prepared the manuscript; $L$ supervised the experiment; GWJ designed the experiment and supervised the project. All authors have read and approved the final manuscript.

\section{Competing interests}

The authors declare that they have no competing interests.

Received: 31 July 2010 Accepted: 8 November 2010 Published: 8 November 2010

\section{References}

1. Alkema MJ, Bronk M, Verhoeven E, Otte A, van 't Veer LJ, Berns A, van Lohuizen M: Identification of Bmi-1 interacting proteins as constituents of a multimeric mammalian Polycomb complex. Genes Dev 1997, 11:226-240.

2. Jacobs JJ, van Lohuizen M: Polycomb repression:from cellular memory to cellular proliferation and cancer. Biochim Biophys Acta 2002, 1602:151-161.

3. Leung C, Lingbeek M, Shakhova O, Liu J, Tanger E, Saremaslani $P$, van Lohuizen M, Marino S: Bmi-1 is essential for cerebellar development and is overexpressed in human medulloblastomas. Nature 2004, 428:337-341. 
4. van der Lugt NM, Domen J, Linders K, van Roon M, Robanus-Maandag E, te Riele $\mathrm{H}$, van der Valk M, Deschamps J, Sofroniew M, van Lohuizen M: Posterior transformation, neurological abnormalities and severe hematopoietic defects inmicewith a targeted deletion of the bmi-1 proto-oncogene. Genes Dev 1994, 8:757-769.

5. Koga H, Kaji Y, Nishii K, Shirai M, Tomotsune D, Osugi T, Sawada A, Kim JY, Hara J, Miwa T, Yamauchi-Takihara K, Shibata Y, Takihara Y: Overexpression of Polycomb-group gene rae28 in cardiomyocytes does not complement abnormal cardiacmorphogenesis inmice lacking rae28 but causes dilated cardiomyopathy. Lab Invest 2002, 82:375-385.

6. Caretti G, DiPadova M, Micales B, Lyons GE, Sartorelli V: The Polycomb Ezh2 methyltransferase regulates muscle gene expression and skeletalmuscle differentiation. Genes Dev 2004, 18:2627-2638.

7. Alkema MJ, van der Lugt NM, Bobeldijk RC, Berns A, Koseki H: Transformation of axial skeleton due to overexpression of bmi-1 in transgenic mice. Nature 1996, 374:724-727.

8. Heard E: Recent advances in X-chromosome inactivation. Curr Opin Cell Biol 2004, 16:247-255

9. Lessard J, Baban D, Sauvageau G: Stage-specific expression of polycomb group genes in human bone marrow cells. Blood 1998, 91:1216-1224.

10. Lessard J, Schumacher A, Thorsteinsdottir U, van Lohuizen M, Magnuson T, Sauvageau G: Functional antagonism of the Polycomb-group genes eed and Bmi-1 in hemopoietic cell proliferation. Genes Dev 1999, 13:2691-2703.

11. Peytavi R, Hong SS, Gay B, d'Angeac AD, Selig L, Bénichou S, Benarous R, Boulanger P: HEED, the product of the human homolog of the murine eed gene, binds to the matrix protein of HIV-1. J Biol Chem 1999, 274:1635-1645

12. Fukuyama T, Otsuka T, Shigematsu H, Uchida N, Arima F, Ohno $Y$, Iwasaki $H$, Fukuda T, Niho Y: Proliferative involvement of ENX-1, a putative human polycomb group gene, in haematopoietic cells. Br J Haematol 2000, 108:842-847.

13. Raaphorst FM, Otte AP, van Kemenade FJ, Blokzijl T, Fieret E, Hamer KM, Satijn DPE, Otte AP, Meijer CJLM: Coexpression of BMl-1 and EZH2 polycomb group genes in Reed-Sternberg cells of Hodgkin's disease. Am J Pathol 2000, 157:709-715.

14. Raaphorst FM, Otte AP, van Kemenade FJ, Blokzijl T, Fieret E, Hamer KM, Satijn DPE, Meijer CJLM: Distinct BMI-1and EZH2 expression patterns in thymocytes and matureT cells suggest a role for Polycomb genes in humanTcell differentiation. J Immunol 2001, 166:5925-5934.

15. Raaphorst FM: Deregulated expression of polycomb-group oncogenes in human malignant lymphomas and epithelial tumours. Hum Mol Genet 2005, 14:93-100.

16. Valk-Lingbeek ME, Bruggeman SW, van Lohuizen M: Stem cells and cancer; the polycomb connection. Cell 2004, 118:409-418.

17. Gil J, Bernard D, Peters G: Role of Polycomb group proteins in stem cellrenewal and cancer. DNA Cell Biol 2005, 24:117-125.

18. Haupt $Y$, Alexander WS, Barri G, Klinken SP, Adams J: Novel zinc finger gene implicated as myc collaborator by retrovirally accelerated lymphomagenesis in Emu-myc transgenic mice. Cell 1991, 65:753-763.

19. van Lohuizen M, Frasch M, Wientjens $E$, Berns A: Sequence similarity between the mammalian bmi-1 proto-oncogene and the Drosophila regulatory genes PsC and Su(z)2. Nature 1991, 353:353-355.

20. Brunk BP, Martin EC, Adler PN: Drosophila genes Posterior Sex Combs and Suppressor two of zeste encode proteins withh omology to the murine bmi-1 oncogene. Nature 1991, 353:351-353.

21. Haupt $Y$, Bath ML, Harris AW, Adams J: Bmi-1 transgene induces lymphomas and collaborates with myc in tumourigenesis. Oncogene 1993, 8:3161-3164

22. Alkema M, Wiegant J, Raap AK, Bems A, van Lohuizen M: Characterization and chromosomal localization of the human proto-oncogene BMI-1. Hum Mol Genet 1993, 2:1597-1603.

23. Beà $S$, Tort $F$, Pinyol $M, P$ uig $X$, Hernández L, Hernández $S$, Fernández $P L$, van Lohuizen M, Colomer D, Campo E: BMI-1 gene amplification and overexpression in hematological malignancies occur mainly in mantle cell lymphomas. Cancer Res 2001, 61:2409-2412.

24. Jacobs JJ, Scheijen B, Voncken JW, Kieboom K, Berns A, van Lohuizen M: Bmi-1collaborates with c-Myc in tumourigenesis by inhibiting c-Myc-induced apoptosis via INK4a/ARF. Genes Dev 1999, $13: 2678-2690$
25. Jacobs JJ, Kieboom K, Marino S, DePinho RA, van Lohuizen M: The oncogene and Polycomb-group gene bmi-1regulates cell proliferation and senescence through the ink4a locus. Nature 1999, 397:164-168.

26. Sherr CJ: The INK4/ARF network in tumour suppression. Nat Rev 2001, 2:731-737.

27. Dimri GP, Martinez JL, Jacobs JJ, Keblusek P, Itahana K, Van Lohuizen M, Campisi J, Wazer DE, Band V: The Bmi-1 oncogene induces telomerase activity and immortalizes human mammary epithelial cells. Cancer Res 2002, 62:4736-4745.

28. Kim JH, Yoon SY, Jeong SH, Kim SY, Moon SK, Joo JH, Lee Y, Choe IS, Kim JW: Overexpression of Bmi-1 oncoprotein correlates with axillary lymph node metastases in invasive ductal breast cancer. Breast 2004, 13:383-388.

29. Kim JH, Yoon SY, Kim CN, Joo JH, Moon SK, Choe IS, Choe YK, Kim JW: The Bmi-1 oncoprotein is overexpressed in human colorectal cancer and correlates with the reduced p16INK4a/p14ARF proteins. Cancer Lett 2004, 203:217-224

30. Song LB, Zeng MS, Liao WT, Zhang L, Mo HY, Liu WL, Shao JY, Wu QL, Li MZ, Xia YF, Fu LW, Huang WL, Dimri GP, Band V, Zeng YX: Bmi-1 is a novel molecular marker of nasopharyngeal carcinoma progression and immortalizes primary human nasopharyngeal epithelial cells. Cancer Res 2006, 66:6225-6232.

31. Mihic-Probst D, Kuster A, Kilgus S, Bode-Lesniewska B, Ingold-Heppner B, Leung C, Storz M, Seifert B, Marino S, Schraml P, Dummer R, Moch H: Consistent expression of the stem cell renewal factor BMI-1 in primary and metastatic melanoma. Int J Cancer 2007, 121:1764-1770.

32. Liu JH, Song LB, Zhang X, Guo BH, Feng Y, Li XX, Liao WT, Zeng MS, Huang $\mathrm{KH}$ : Bmi-1 expression predicts prognosis for patients with gastric carcinoma. J Surg Oncol 2008, 97:267-272.

33. Zhang XW, Sheng YP, Li Q, Qin W, Lu YW, Cheng YF, Liu BY, Zhang FC, Li J, Dimri GP, Guo WJ: Bmi-1 and Mel-18 oppositely regulate carcinogenesis and progression of gastric cancer. Mol Cancer 2010, 21(9):40.

34. Qin ZK, Yang JA, Ye YL, Zhang X, Xu LH, Zhou FJ, Han H, Liu ZW, Song LB, Zeng MS: Expression of Bmi-1 is a prognostic marker in bladder cancer. BMC Cancer 2009, 9:61-67.

35. Lessard J, Sauvageau G: Bmi-1 determines the proliferative capacity of normal and leukaemic stem cells. Nature 2003, 423:255-260.

36. Park I, Qian D, Kiel M, Becker MW, Pihalja M, Weissman IL, Morrison SJ, Clarke MF: Bmi-1 is required for maintenance of adult self-renewing haematopoietic stem cells. Nature 2003, 423:302-305.

37. Liu S, Dontu G, Mantle ID, Patel S, Ahn NS, Jackson KW, Suri P, Wicha MS: Hedgehog signaling and Bmi-1 regulate self-renewal of normal and malignant human mammary stem cells. Cancer Res 2006, 66:6063-6071.

38. Guo WJ, Zeng MS, Yadav A, Song LB, Guo BH, Band V, Dimri GP: Mel-18 acts as a tumor suppressor by repressing Bmi-1 expression and downregulating Akt activity in breast cancer cells. Cancer Res 2007, 67:5083-5089.

39. Kajiume T, Ohno N, Sera Y, Kawahara Y, Yuge L, Kobayashi M: Reciprocal expression of Bmi-1 and Mel-18 is associated with the functioning of primitive hematopoietic cells. Exp Hematol 2009, 37:857-866.

40. Lee JY, Jang KS, Shin DH, Oh MY, Kim HJ, Kim Y, Kong G: Mel-18 negatively regulates INK4a/ARF-independent cell cycle progression via Akt inactivation in breast cancer. Cancer Res 2008, 68:4201-4209.

41. Wiederschain D, Chen L, Johnson B, Bettano K, Jackson D, Taraszka J, Wang YK, Jones MD, Morrissey M, Deeds J, Mosher R, Fordjour P, Lengauer C, Benson JD: Contribution of polycomb homologues Bmi-1 and Mel-18 to medulloblastoma pathogenesis. Mol Cell Biol 2007, 27:4968-4979.

42. Silva J, García JM, Peña C, García V, Domínguez G, Suárez D, Camacho Fl, Espinosa R, Provencio M, España P, Bonilla F: Implication of polycomb members Bmi-1, Mel-18, and Hpc-2 in the regulation of p16INK4a, p14ARF, h-TERT, and c-Myc expression in primary breast carcinomas. Clin Cancer Res 2006, 12:6929-6936.

43. Guo WJ, Datta S, Band V, Dimri GP: Mel-18, a Polycomb Group Protein Regulates Cell Proliferation and Senescence via Transcriptional Repression of Bmi-1 and c-Myc Oncoproteins. Mol Biol Cell 2007, 18:536-546.

44. Gunster MJ, Satijn DPE, Hamer KM, den Blaauwen JL, de Bruijn D, Alkema MJ, van Lohuizen M, van Driel R, Otte AP: Identification and characterization of interactions between the vertebrate Polycomb-group 
protein BMI-1 and human homologs of Polyhomeotic. Mol Cell Biol 1997, $17: 2326-2335$

45. Hashimoto N, Brock HW, Nomura M, Kyba M, Hodgson J, Fujita Y, Takihara Y, Shimada K, Higashinakagawa T: Rae28, Bmi-1, and M33 are members of heterogeneous multimeric mammalian Polycomb group complexes. Biochem Biophys Res Commun 1997, 245:356-365.

46. Shao Z, Raible F, Mollaaghababa R, Guyon JR, Wu CT, Bender W, Kingston RE: Stabilization of chromatin structure by PRC1, a Polycomb complex. Cell 1999, 98:37-46.

47. Francis NJ, Saurin AJ, Shao Z, Kingston RE: Reconstitution of a functional core polycomb repressive complex. Mol Cell 2001, 8:545-556.

48. van Kemenade FJ, Raaphorst FM, Blokzijl T, Fieret E, Hamer KM, Satijn DP, Otte AP, Meijer CJ: Coexpression of BMI-1 and EZH2 polycomb-group proteins is associated with cycling cells and degree of malignancy in Bcell non-Hodgkin lymphoma. Blood 2001, 97:3896-3901.

49. Raaphorst FM, Vermeer M, Fieret E, Blokzijl T, Dukers D, Sewalt RGAB, Otte AP, Willemze R, Meijer CJLM: Sitespecific expression of Polycombgroup genes encoding the HPC-HPH/PRC1 complex in clinically defined primary nodal and cutaneous large B-cell lymphomas. Am J Pathol 2004, 164:533-542.

50. Visser HP, Gunster MJ, Kluin-Nelemans HC, Manders EM, Raaphorst FM, Meijer CJ, Willemze R, Otte AP: The Polycomb group protein EZH2 is upregulated in proliferating,cultured human mantle cell lymphoma. $\mathrm{Br} J$ Haematol 2001, 112:950-958.

51. Dukers DF, van Galen JC, Giroth C, Jansen P, Sewalt RGAB, Otte AP, KluinNelemans HC, Meijer CJLM, Raaphorst FM: Unique Polycomb gene expression pattern in Hodgkin's lymphoma and Hodgkin's lymphomaderived cell lines. Am J Pathol 2004, 164:873-881.

52. Sánchez-Beato M, Sánchez E, García JF, Pérez-Rosado A, Montoya MC, Fraga M, Artiga MJ, Navarrete M, Abraira V, Morente M, Esteller M, Koseki H, Vidal M, Piris MA: Abnormal PcG protein expression in Hodgkin's lymphoma.Relation withE2F6 and NfkappaB transcription factors. J Pathol 2004, 204:528-537.

53. Vonlanthen S, Heighway J, Altermatt HJ, Gugger M, Kappeler A, Borner MM, van Lohuizen M, Betticher DC: The bmi-1 oncoprotein is differentially expressed in nonsmall cell lung cancer and correlates with INK4A-ARF locus expression. Br J Cancer 2001, 84:1372-1376.

54. Neo SY, Leow CK, Vega VB, Long PM, Islam AF, Lai PB, Liu ET, Ren EC: Identification of discriminators of hepatoma by gene expression profiling using a minimal dataset approach. Hepathology 2004, 39:944-953.

55. Ferreux E, Lont AP, Horenblas S, Gallee MP, Raaphorst FM, von Knebel Doeberitz M, Meijer CJ, Snijders PJ: Evidence for at least three alternative mechanisms targeting the $\mathrm{p} 16 \mathrm{INK} 4 \mathrm{~A} / \mathrm{cyclin} \mathrm{D} / \mathrm{Rb}$ pathway in penile carcinoma,one of which is mediated by high-risk human papillomavirus. J Pathol 2003, 201:109-118.

56. Raaphorst FM, Meijer CJ, Fieret E, Blokzijl T, Mommers E, Buerger $\mathrm{H}_{\text {, }}$ Packeisen J, Sewalt RA, Otte AP, van Diest PJ: Poorly differentiated breast carcinoma is associated with increased expression of the human polycomb group EZH2 gene. Neoplasia 2003, 5:481-488.

57. Kim JH, Yoon SY, Kim CN, Joob JH, Moona SK, Choeb IS, Choeb YK, Kimb JW: The Bmi-1 oncoprotein is overexpressed in human colorectal cancer and correlates with the reduced p16INK4a/p14ARF proteins. Cancer Lett 2004, 203:217-224.

58. Varambally S, Dhanasekaran SM, Zhou M, Barrette TR, Kumar-Sinha C, Sanda MG, Ghosh D, Pienta KJ, Sewalt RGAB, Otte AP, Rubin MA, Chinnaiyan AM: The Polycomb group protein EZH2 is involved in progression of prostate cancer. Nature 2002, 419:624-629.

59. Datta S, Hoenerhoff MJ, Bommi P, Sainger R, Guo WJ, Dimri M, Band H, Band V, Green JE, Dimri GP: Bmi-1 Cooperates with H-Ras to Transform Human Mammary Epithelial Cells via Dysregulation of Multiple GrowthRegulatory Pathways. Cancer Res 2007, 67:10286-10295.

60. Wang Q, Li WL, You P, Su J, Zhu MH, Xie DF, Zhu HY, He ZY, Li JX, Ding XY, Wang $X$, Hu YP: Oncoprotein BMI-1 induces the malignant transformation of HaCaT cells. J Cell Biochem 2009, 106:16-24.

61. Zhao J, Luo XD, Da CL, Xin Y: Clinicopathological significance of B-cellspecific Moloney murine leukemia virus insertion site 1 expression in gastric carcinoma and its precancerous lesion. World J Gastroenterol 2009, 15:2145-2150.

62. Tagawa M, Sakamoto T, Shigemoto K, Matsubara H, Tamura Y, Ito T, Nakamura I, Okitsu A, Imai K, Taniguchi M: Expression of novel DNA- binding protein with zinc finger structure in various tumor cells. J Biol Chem 1990, 265:20021-20026.

63. Tetsu O, Ishihara H, Kanno R, Kamiyasu M, Inoue H, Tokuhisa T, Taniguchi M, Kanno M: Mel-18 negatively regulates cell cycle progression upon B cell antigen receptor stimulation through a cascade leading to c-myc/cdc25. Immunity 1998, 9:439-448.

64. Kanno M, Hasegawa M, Ishida A, Isono K, Taniguchi M: mel-18, a Polycomb group-related mammalian gene, encodes a transcriptional negative regulator with tumor suppressive activity. EMBO J 1995, 14:5672-5678.

doi:10.1186/1756-9966-29-143

Cite this article as: Lu et al:: Expression and clinicopathological significance of Mel-18 and Bmi-1 mRNA in gastric carcinoma. Journal of Experimental \& Clinical Cancer Research 2010 29:143.

\section{Submit your next manuscript to BioMed Central and take full advantage of:}

- Convenient online submission

- Thorough peer review

- No space constraints or color figure charges

- Immediate publication on acceptance

- Inclusion in PubMed, CAS, Scopus and Google Scholar

- Research which is freely available for redistribution

Submit your manuscript at www.biomedcentral.com/submit
Biomed Central 